\title{
Impact of Land Cover Composition and Structure on Air Temperature Based on the Local Climate Zone Scheme in Hangzhou, China
}

\author{
Hai Yan ${ }^{1}$, Shimin Yang ${ }^{1}$, Xiaohui Guo ${ }^{1}$, Fan $W u^{2}$, Renwu $W u^{1}$, Feng Shao ${ }^{1}$ and Zhiyi Bao ${ }^{1, *}$ \\ 1 School of Landscape Architecture, Zhejiang A \& F University, Hangzhou 311300, China; \\ yanhai@zafu.edu.cn (H.Y.); yangshimin2020@126.com (S.Y.); guoxh123@126.com (X.G.); \\ wurenwu0034@163.com (R.W.); shaofeng@zafu.edu.cn (F.S.) \\ 2 School of Civil Engineering and Architecture, Zhejiang Sci-Tech University, Hangzhou 310018, China; \\ wufan@zstu.edu.cn \\ * Correspondence: bao99928@188.com
}

Citation: Yan, H.; Yang, S.; Guo, X.; Wu, F.; Wu, R.; Shao, F.; Bao, Z. Impact of Land Cover Composition and Structure on Air Temperature Based on the Local Climate Zone Scheme in Hangzhou, China. Atmosphere 2021, 12, 936. https:// doi.org/10.3390/atmos12080936

Academic Editor: Edward Wolf

Received: 20 June 2021

Accepted: 19 July 2021

Published: 21 July 2021

Publisher's Note: MDPI stays neutral with regard to jurisdictional claims in published maps and institutional affiliations.

Copyright: (c) 2021 by the authors. Licensee MDPI, Basel, Switzerland. This article is an open access article distributed under the terms and conditions of the Creative Commons Attribution (CC BY) license (https:// creativecommons.org/licenses/by/ $4.0 /)$.

\begin{abstract}
At present, conflicts between urban development and the climate environment are becoming increasingly apparent under rapid urbanization in China. Revealing the dynamic mechanism and controlling factors of the urban outdoor thermal environment is the necessary theoretical preparation for regulating and improving the urban climate environment. Taking Hangzhou as an example and based on the local climate zones classification system, we investigated the effects of land cover composition and structure on temperature variability at the local scale. The measurement campaign was conducted within four local climate zones (LCZ 2, 4, 5, and LCZ 9) during 7 days in the summer of 2018. The results showed that the temperature difference within the respective LCZ was always below $1.1^{\circ} \mathrm{C}$ and the mean temperature difference between LCZs caused by different surface physical properties was as high as $1.6^{\circ} \mathrm{C}$ at night. Among four LCZs, LCZ 2 was always the hottest, and LCZ 9 was the coolest at night. In particular, the percentage of pervious surface was the most important land cover feature in explaining the air temperature difference. For both daytime and nighttime, increasing the percentage of pervious surface as well as decreasing the percentage of impervious surface and the percentage of building surface could lower the local temperature, with the strongest influence radius range from $120 \mathrm{~m}$ to $150 \mathrm{~m}$. Besides, the temperature increased with the SVF increased at day and opposite at night.
\end{abstract}

Keywords: urban heat island; local climate zones; air temperature; land cover composition; sky view factor

\section{Introduction}

A distinct characteristic of the urban climate is the urban heat island (UHI), which refers to the phenomenon that air/surface temperatures in urban areas are higher than that in the surrounding rural areas due to urbanization [1]. The UHI effect has been widely observed in big-, medium-, and small-sized cities in the world, regardless of their latitude, location, topography, and environment, and the intensity of UHI increases with the development of cities [2-4]. The higher temperature caused by UHI not only affects the living environment and health of city residents, but also increases energy consumption and consequently increases the emission of pollutants and greenhouse gases [5-9]. With global warming and a new round of urbanization, the UHI will affect a larger number of urban dwellers [10]. Therefore, it is of great significance to study the main influencing factors of the UHI effect for improving the urban thermal environment and urban livability.

The urban air temperature is influenced by the urban land cover features, which has long been recognized by urban climatologists in practice. The relationship between air temperature and land cover composition is one of the key issues in urban climate research. A number of studies have reported that vegetation and some other types of land cover, 
such as built-up surface, impervious surface, and water body, substantially affect intraurban air temperature distributions and urban heat island intensity [11-14]. Higher air temperatures usually result from higher building densities, increased impervious surface, and reduced permeable natural vegetation covers [15,16]. Yan et al. [17], for example, found that land cover features have a great influence on the magnitude and spatial characteristic of the urban air temperature variations. Increasing the amount of greenspace can be an effective means to decrease air temperature, while the increase of building surface would significantly increase it. In Xi'an, a similar result was observed by $\mathrm{Xu}$ et al. [18], an indication that around $66 \%$ of the urban air temperature variability could be explained by the building footprint ratio and that approximately $50 \%$ of the intra-urban heat island intensity variability could be explained by the green land cover.

In addition to the land cover composition, the three-dimensional geometric structure of the land cover also has an impact on the urban outdoor thermal environment. The urban land cover structure largely determines air flow, solar radiation, and long-wave radiation of the ground, so that the climate of the urban canopy becomes extremely complex [19-21]. An important measure of the structural characteristics of the urban underlying surface is the sky view factor (SVF), which refers to the fraction of the overlying hemisphere occupied by the sky [22]. Lots of studies have shown that SVF has a great influence on the intra-urban air temperature as well as the intensity and spatial pattern of UHI [23-25].

However, there are various types of land use in our cities, forming different urban forms and underlying surface types. Therefore, the primary task of studying the urban heat island problem is dividing urban surface types reasonably. The local climate zone (LCZ) classification system developed by Stewart and Oke [26], which aims at facilitating consistent relevant classifications of urban areas for air temperature measurements, explicitly assigns specific classes to areas of similar land cover features and provides a proper framework for fully understanding local-scale climate studies. The LCZ classification system comprises 17 classes of area at the local scale by certain standards. Each class is based on several surface structure, morphological, and anthropogenic parameters. The applicability of the LCZ classification system for different urban climate study domains has been well established by various researchers. In most of these studies, which included both fixed and mobile methods, data were collected in calm and clear conditions [27-33]. The effectiveness and universality of this classification system was verified in multiple cities by field measurements and temperature simulations. Leconte et al. [34] found that the classification of local climate zones can be properly used for elementary information of neighborhoods around the climate station. Geletič et al. [35] analyzed the differences of land surface air temperatures in several European cities based on the LCZ theory using traverse measurements.

Different LCZs have general temperature patterns, and some researchers have confirmed that thermal contrasts between day and night exist among all LCZs. Such contrasts are governed primarily by the pervious surface fraction, street aspect ratio, tree canopy coverage, and soil wetness [30,36-38]. According to a simulation of different LCZs during both day and night, the LCZ 1 (compact high-rise), which showed a higher nocturnal temperature than other LCZs, has the lowest temperature difference between day and night, and LCZ D has the highest temperature difference [26,34]. Additionally, LCZ 1 has a lower diurnal temperature than other LCZs and has a diurnal cool island effect. Moreover, the same LCZs within a city have similar temperature conditions [34].

However, most of the existing field monitoring research of the LCZ scheme has been conducted from cites in North America and Europe. These cities are very different from the cities of China in terms of city size, land cover features, and climate characteristics. We chose a residential zone as the study area, which is one of the important daily living environments for urban residents. Besides, considering the influence of heat events in summer, we chose the summer condition as our study season. This study aimed to provide insights into this subject by focusing on the quantitative relationship between the land cover features and air temperature of several LCZ classes in Hangzhou, China. Specifically, 
we aimed to elucidate: (1) How large is the air temperature differences between each LCZ, as well as within the respective environment; and (2) how do the land cover composition and structure features differentially contribute to explaining the air temperature difference?

\section{Methodology}

\subsection{Study Area}

Hangzhou, the capital of Zhejiang Province, is located in the east of China. The study was conducted in Lin'an district $\left(30^{\circ} 23^{\prime} \mathrm{N}, 119^{\circ} 72^{\prime} \mathrm{E}\right)$ located in the west of Hangzhou (Figure 1). According to Köppern-Geiger climate classification, the climate of Lin'an is Cfa (C: Mild temperate, f: Fully humid, a: Hot summer) [39,40]. It has a subtropical monsoon climate characterized by hot summers and cold winters with an annual mean air temperature of $16.2^{\circ} \mathrm{C}(1981-2010)$. July is the warmest month with an average air temperature of about $28.9^{\circ} \mathrm{C}$, while January is the coolest month with an average air temperature of about $4.6^{\circ} \mathrm{C}$. As one of the central cities in the Yangtze River Delta Economic Circle, urban space has expanded fast with the rapid economic development of Hangzhou. Along with the change of land use and land cover, the urban thermal environment has also changed. In recent years, the summer high temperature in Hangzhou has been extremely obvious. The urban heat island effect has further aggravated the high-temperature weather, leading to deterioration of the urban thermal environment.

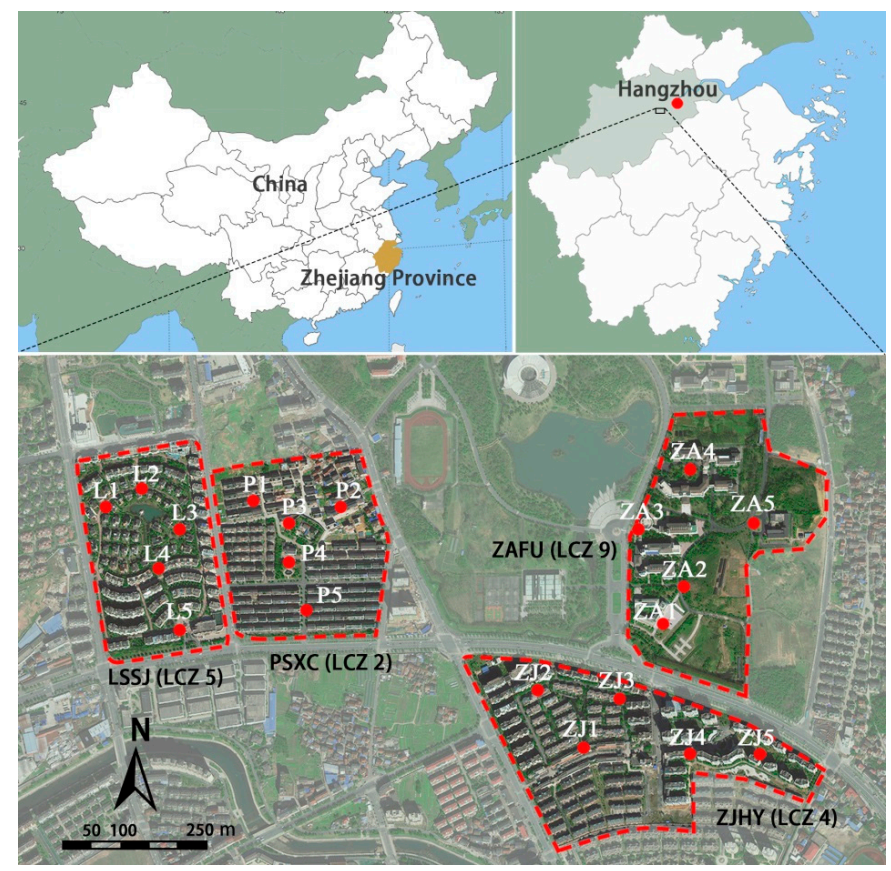

Figure 1. Location of the study area and measurement points.

The measurements were performed in the downtown of Lin'an district, which can be seen as a typical area urbanizing rapidly in Hangzhou. The LCZ classification of Lin'an was based on field surveys and calculations from aerial photographs. Based on the classification results of the LCZ, we chose four types of different landscape areas with various underlying land cover surfaces, including three residential areas and one university since they represent the most prevalent LCZs in Lin'an (Table 1). According to the LCZ classification standards [26], Ping Shan Xin Cun (PSXC) can be classified as LCZ 2 (compact midrise), Zhu Jing Hua Yuan (ZJHY) can be classified as LCZ 4 (open high-rise), Lin Shui Shan Ju (LSSJ) can be classified as LCZ 5 (open midrise), and the Zhejiang Agriculture and Forestry University (ZAFU) can be classified as LCZ 9 (sparsely built). We selected 5 measurement points in each LCZs, resulting in 20 points in total (Figure 1). 


\subsection{Field Measurements}

We used mobile methods to conduct air temperature measurement in each local climate zone on 7 typical days during the summer of 2018 (15t to 27 June, clear and smooth day with minimum cloud and wind speed was less than $3 \mathrm{~m} / \mathrm{s}$ ). On each day, measurements were conducted at 14:00 (daytime) and 21:00 (nighttime) along a fixed route with a distance of $7.1 \mathrm{~km}$, and each measurement lasted about $1 \mathrm{~h}$. During the study period, the maximum and minimum air temperatures were 37.1 and $23.8^{\circ} \mathrm{C}$, respectively, within the study area.

Table 1. Landscape parameters of each study site.

\begin{tabular}{|c|c|c|c|c|c|c|c|c|}
\hline \multirow{2}{*}{ Site } & \multirow{2}{*}{ LCZ } & \multirow{2}{*}{ Built Types } & \multirow{2}{*}{ Area $\left(\mathrm{ha}^{2}\right)$} & \multirow{2}{*}{ MBH (m) } & \multirow{2}{*}{ Plant Species } & \multicolumn{3}{|c|}{ Land Cover Composition (\%) } \\
\hline & & & & & & PerPS & PerIS & PerBS \\
\hline PSXC & $\mathrm{LCZ} 2$ & & 12.7 & 14 & $\begin{array}{l}\text { Osmanthus fragrans } \\
\text { Iris tectorum }\end{array}$ & 17.87 & 41.31 & 40.82 \\
\hline ZJHY & $\mathrm{LCZ} 4$ & & 14.6 & 27 & $\begin{array}{l}\text { Liriodendron chinense } \\
\text { Ginkgo biloba } \\
\text { Cinnamomum camphora }\end{array}$ & 38.52 & 33.76 & 27.72 \\
\hline LSSJ & LCZ 5 & & 10.9 & 15 & $\begin{array}{c}\text { Magnolia grandiflora } \\
\text { Ginkgo biloba } \\
\text { Prunus mume }\end{array}$ & 42.14 & 27.32 & 30.54 \\
\hline ZAFU & LCZ 9 & $\operatorname{los}_{n \rightarrow 0}$ & 16.0 & 12 & $\begin{array}{c}\text { Ginkgo biloba } \\
\text { Michelia chapensis } \\
\text { Magnolia grandiflora }\end{array}$ & 60.29 & 26.89 & 12.82 \\
\hline
\end{tabular}

Note: MBH, PerPS, PerIS, and PerBS refer to the mean building height, the percentage of pervious surface, the percentage of impervious surface, and the percentage of building surface, respectively.

Air temperatures were measured by thermistor temperature sensors (TES-1365, sensor accuracy: air temperature $\pm 0.5{ }^{\circ} \mathrm{C}$, relative humidity $\pm 3-5 \%$ ) connected to a data logger shaded with a radiation shield. The instrument was mounted onto the front of an electromobile $(15 \mathrm{~km} / \mathrm{h})$ at $1.5 \mathrm{~m}$ above ground. The instant information, including latitude, longitude, and time, was recorded by a GPS travel recorder (Holux M-241A). The HOBO weather station used for fixed measurements was installed in each LCZ region. These data were mainly used to correct the data of mobile measurements because the mobile measurements at different points were not instantaneous.

\subsection{Land Cover Parameters Measurement and Calculation}

Considering the potential effects of land cover on urban temperatures, we selected two categories of land cover parameters, including land cover composition and structure, to measure the characteristics of the local environments (Figure 2). Land cover composition includes the percentage of pervious surface (PerPS), percentage of impervious surface (PerIS), and percentage of built-up surface (PerBS). The sky view factor (SVF) was used to quantify land cover structure.

We used satellite photos downloaded from Google Maps (18 May 2017) to evaluate the land cover features in the measurement area. According to previous research, the air temperature in an urban site is mainly affected by its surrounding land cover within a few hundred meters [41,42]. Thus, we chose buffer zones with radii of 15, 30, 60, 90, 120, 150, and $180 \mathrm{~m}$ in our study. By drawing corresponding areas on the aerial photographs with AutoCAD 2018 and on-site investigation, we calculated the percentages of vegetation cover, impervious area, and build-up area for each site (Figure 2b). The SVF images were taken by a Sigma $8 \mathrm{~mm}$ circular fisheye lens coupled to a Cannon EOS 6D Mark II (Canon Inc., Japan) digital camera (Figure 2c). Then, we used RayMan1.2 software for the SVF calculation. 


\subsection{Data Analysis}

We first calculated the average air temperature of four study areas as the mean temperature of each time. For each LCZ, the air temperature differences were calculated as follows:

Air temperature difference $\left({ }^{\circ} \mathrm{C}\right)$ :

$$
\mathrm{dAT}=\mathrm{Tw}, \mathrm{t}-\mathrm{Ta}, \mathrm{t}
$$

where $\mathrm{w}$ represents the average air temperature of 7 days in one site $\left({ }^{\circ} \mathrm{C}\right)$; $\mathrm{t}$ represents the time of day, including daytime and nighttime; and a represents the average air temperature in the four sites. Positive or negative dAT indicates whether the site was a hot or cold spot, respectively. A one-way ANOVA F-test $(p<0.05)$ was performed to compare the mean air temperature (AT) among LCZs at both day and night. Then, we analyzed the relationship between the air temperature and the percentage of pervious surface, the percentage of impervious surface, and the percentage of building surface and the SVF by a simple linear regression in different time and radius.
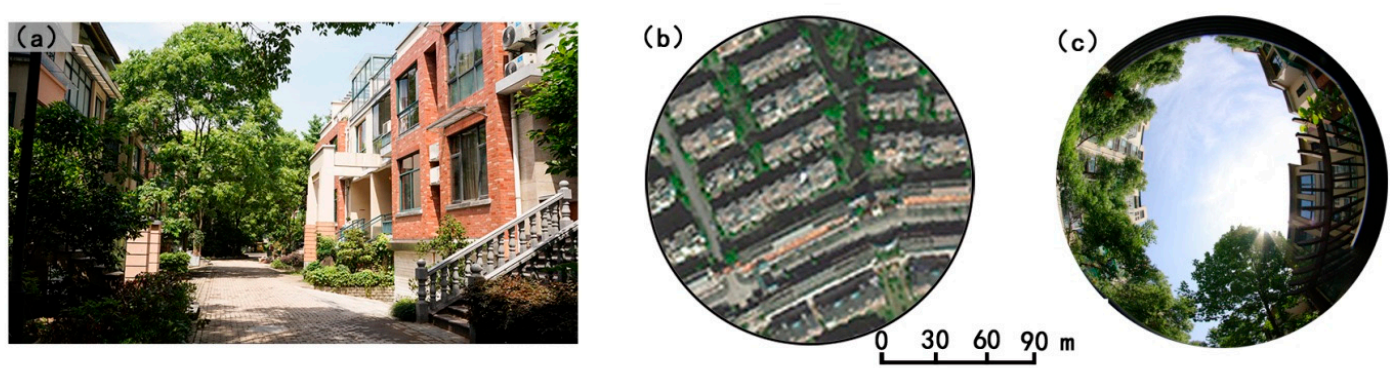

Figure 2. Landscape features of one measurement point (ZJ1). (a) Site photograph, (b) land cover features in the buffer zone, and (c) fish-eye photograph.

\section{Results}

\subsection{Thermal Performance within and between Different LCZs}

The temperature distribution patterns of different local climate zones in the afternoon and night are presented in Figure 3. Within each local climate zone, in the afternoon, the intra-LCZ differentiation of the air temperature ranged from $0.4{ }^{\circ} \mathrm{C}(\mathrm{LCZ} 5$ and 9$)$ to $1.1^{\circ} \mathrm{C}$ (LCZ 4). Additionally, the air temperature difference ranged from 0.3 (LCZ 5) to $1.0^{\circ} \mathrm{C}$ (LCZ 9) in the nighttime.

Figure 4 shows the mean temperature of all measured days in different local climate zones. It can easily be seen that inter-LCZ differentiation of the air temperature was obvious. In the daytime, the microscale variability in AT between PSXC (LCZ 2) and ZJHY (LCZ 4) was $0.8^{\circ} \mathrm{C}$. The order of LCZ temperature was LCZ $2>5>9>4$. The dAT in site ZJHY (LCZ 4) was always below zero; however, the dAT in site PSXC (LCZ 2) was always above zero. While site PSXC was usually the hottest spot during the day, site ZJHY was shown to be the daytime cold spot. During the night, the temperature contrast between PSXC (LCZ 2) and ZAFU (LCZ 9) was as high as $1.6^{\circ} \mathrm{C}$. The order of LCZ temperatures was LCZ $2>4>5>9$. The dAT in site ZAFU (LCZ 9) was always below zero; however, the dATs in site PSXC (LCZ 2) and ZJHY (LCZ 4) were always above zero. Regarding all measurement days, the thermal contrast of LCZs during the daytime was larger than that at nighttime.

The one-way ANOVA F-test $(p<0.05)$ results showed that the mean ATs among LCZ at each time of day had significant differences. Specifically, in the daytime, the mean ATs between PSXC (LCZ 2) and all the other LCZs were significant in all mobile measurements, but the mean ATs between ZJHY (LCZ 4), LSSJ (LCZ 5), and ZAFU (LCZ 9) were not significant. In the nighttime, the mean ATs between PSXC (LCZ 2) and other LCZs were significant in most cases. 
In terms of the order of LCZs at different times, it is worth noting that LCZ 2 always had the highest temperature. This is probably because the percentage of impervious surface of LCZ 2 was higher than the others (Table 1). The ATs of LCZ 4 were much similar to LCZ 5 in our study. Additionally, LCZ 9 always had the lowest temperature in the nighttime between the four LCZs due to the high percentage of pervious surface and the high sky view factor value.

\subsection{The Relationship between Air Temperature and Land Cover Composition}

Each LCZ is individually different from each other in land cover composition, which has a different effect on the outdoor thermal performance. Figure 5 shows the degree of correlation of AT during the two periods of the day with a pervious surface fraction at various spatial extent scales. During the day, PerPS was mainly negatively correlated with AT. During the daytime, there was a weak correlation for the $60 \mathrm{~m}$ radius $\left(\mathrm{R}^{2}=0.328\right.$, $p<0.01$ ), while the correlation was significant for the $30 \mathrm{~m}$ to $60 \mathrm{~m}$ radius. In the nighttime, AT was strongly correlated with PerPS at the spatial scale of $60 \mathrm{~m}$ to $180 \mathrm{~m}$ in radius. Additionally, the greatest correlation was in the $120 \mathrm{~m}$ radius $\left(\mathrm{R}^{2}=0.807, p<0.01\right)$. Every $10 \%$ increase in the PerPS decreased AT by $0.245^{\circ} \mathrm{C}$ in the night when the buffer radius was $120 \mathrm{~m}$.

Figure 6 shows the correlation of AT during two periods in a day with an impervious surface fraction. During the two time periods of the day, PerIS was mainly correlated positively with AT. During the nighttime, the strongest correlation was in the $150 \mathrm{~m}$ radius $\left(\mathrm{R}^{2}=0.587, p<0.01\right)$, while in a radius of $60 \mathrm{~m}$ to $180 \mathrm{~m}$, the correlations were all significant. Every $10 \%$ increase in PerIS increased the AT by $0.107^{\circ} \mathrm{C}$ in the nighttime when the buffer radius was $150 \mathrm{~m}$. However, the strongest correlation in the daytime was not significant even in the $60 \mathrm{~m}$ radius $\left(\mathrm{R}^{2}=0.121, p=0.133\right)$.
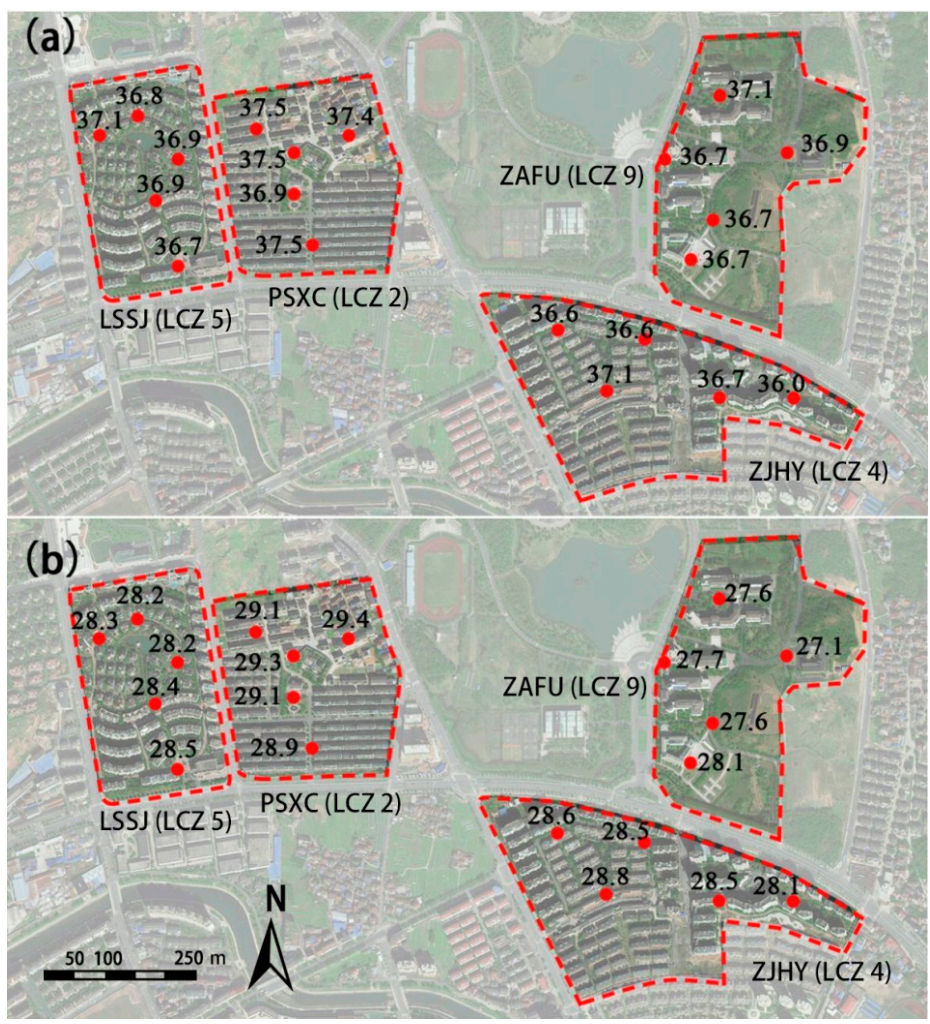

Figure 3. The mean air temperature $\left({ }^{\circ} \mathrm{C}\right)$ in each $\mathrm{LCZ}$ at different times: (a) daytime, (b) nighttime.

Figure 7 shows the correlation of AT during the two periods of the day with a building surface fraction. During the two periods of the day, PerBS mainly correlated positively with AT. In the daytime, the greatest correlation was in the $30 \mathrm{~m}$ radius $\left(\mathrm{R}^{2}=0.293, p<0.05\right)$, 
while in the $30 \mathrm{~m}$ to $90 \mathrm{~m}$ radius, the correlations were all significant. During the nighttime, the strongest correlation was in the $120 \mathrm{~m}$ radius $\left(\mathrm{R}^{2}=0.696, p<0.01\right)$, while in the $30 \mathrm{~m}$ to $180 \mathrm{~m}$ radius, the correlations were all significant. Every $10 \%$ increase in PerBS increased AT by $0.157^{\circ} \mathrm{C}$ in the evening when the buffer radius was $120 \mathrm{~m}$.

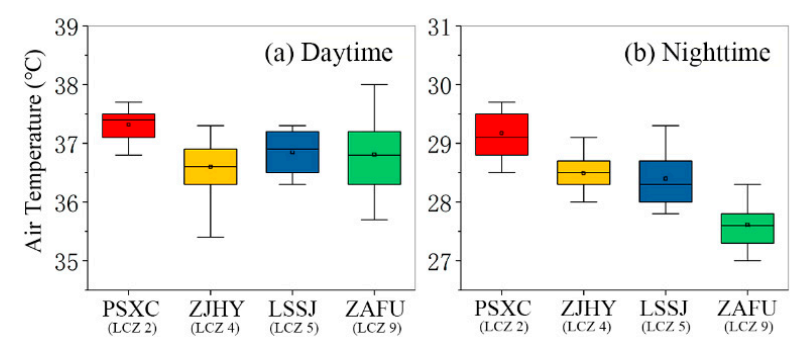

Figure 4. The box plots of the air temperature in each LCZ at different times. (a) Daytime, (b) nighttime. The bulging dots in the middle illustrate the median values.
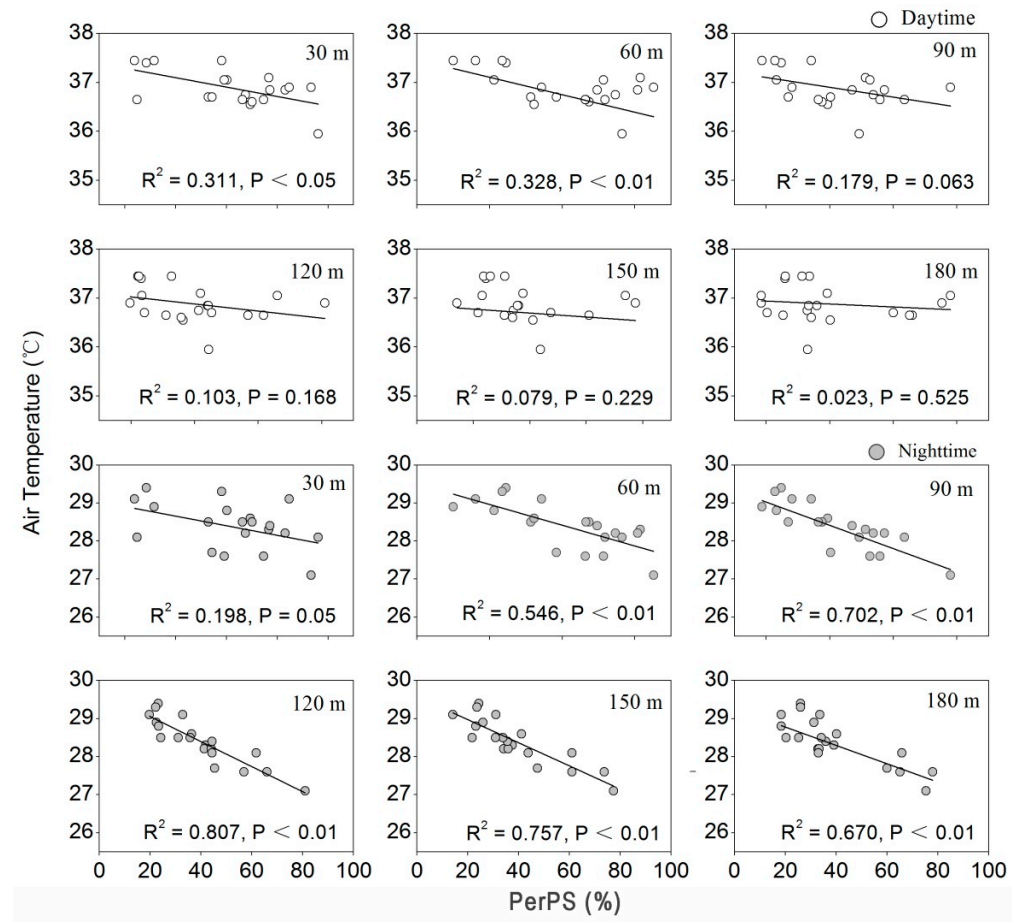

Figure 5. Relationships between air temperature and the percentage of pervious surface in differen radii.

The correlation between the land cover composition features and outdoor thermal performance showed the different contributions of these three factors to the air temperature contrasts. In particular, PerPS was the most important land cover composition in explaining the air temperature contrast, followed by PerBS and the PerIS. In this case, the assumption that LCZ 9, which has a high PerPS, would be the cool one in four LCZs during the night is consistent with the actual measurement result.

\subsection{The Relationship between Air Temperature and Land Cover Structure}

Each LCZ has a specific interval of SVF and aspect ratio, and different structural characteristics have an impact on the urban outdoor thermal environment. During the daytime in summer, the correlation between AT and SVF was positive, and it became negative during the night (Figure 8). However, there was no significant relationship between AT and SVF both in the daytime $\left(\mathrm{R}^{2}=0.003, p=0.814\right)$ and in the nighttime $\left(R^{2}=0.130, p=0.118\right)$. 

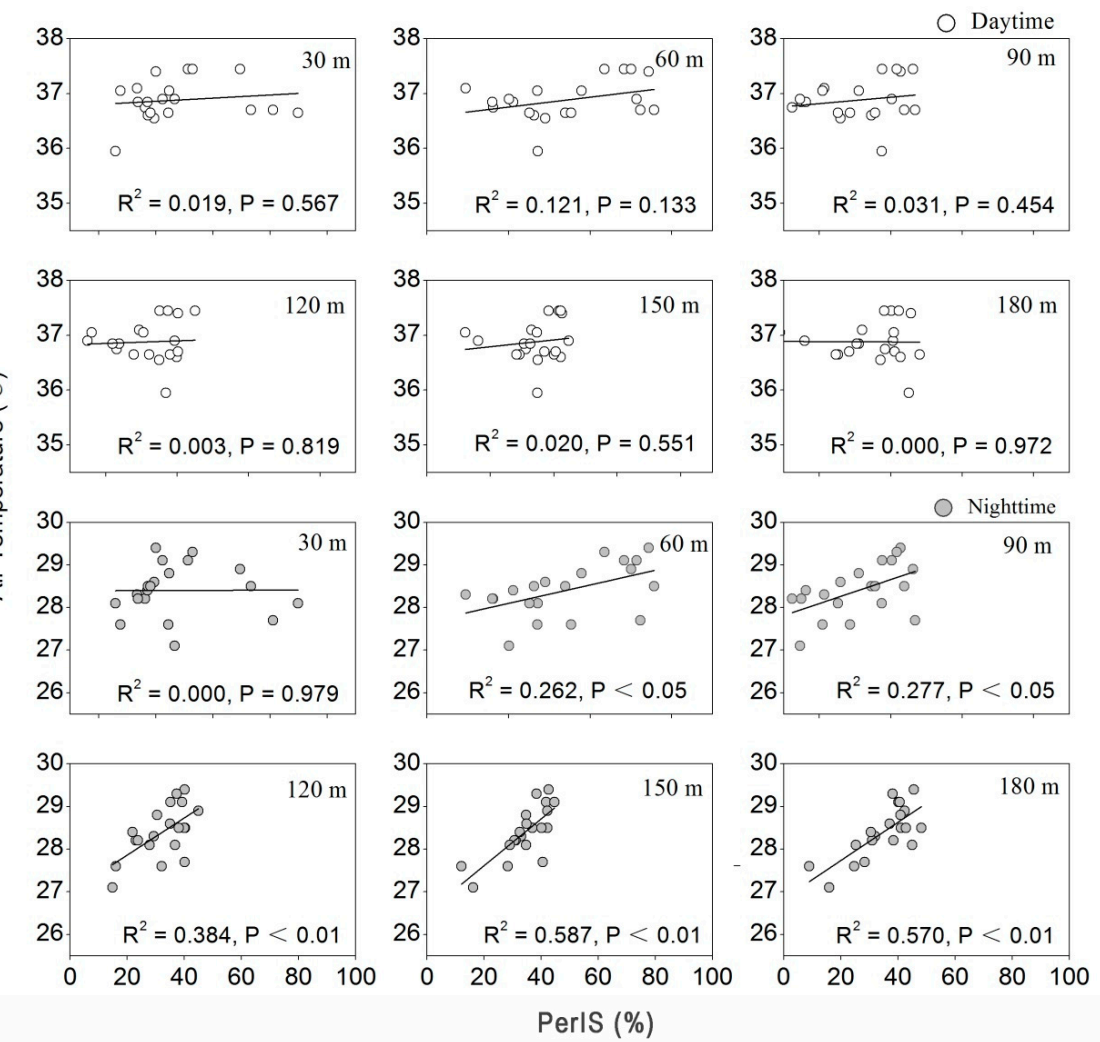

Figure 6. Relationships between air temperature and the percentage of impervious surface in different radii.
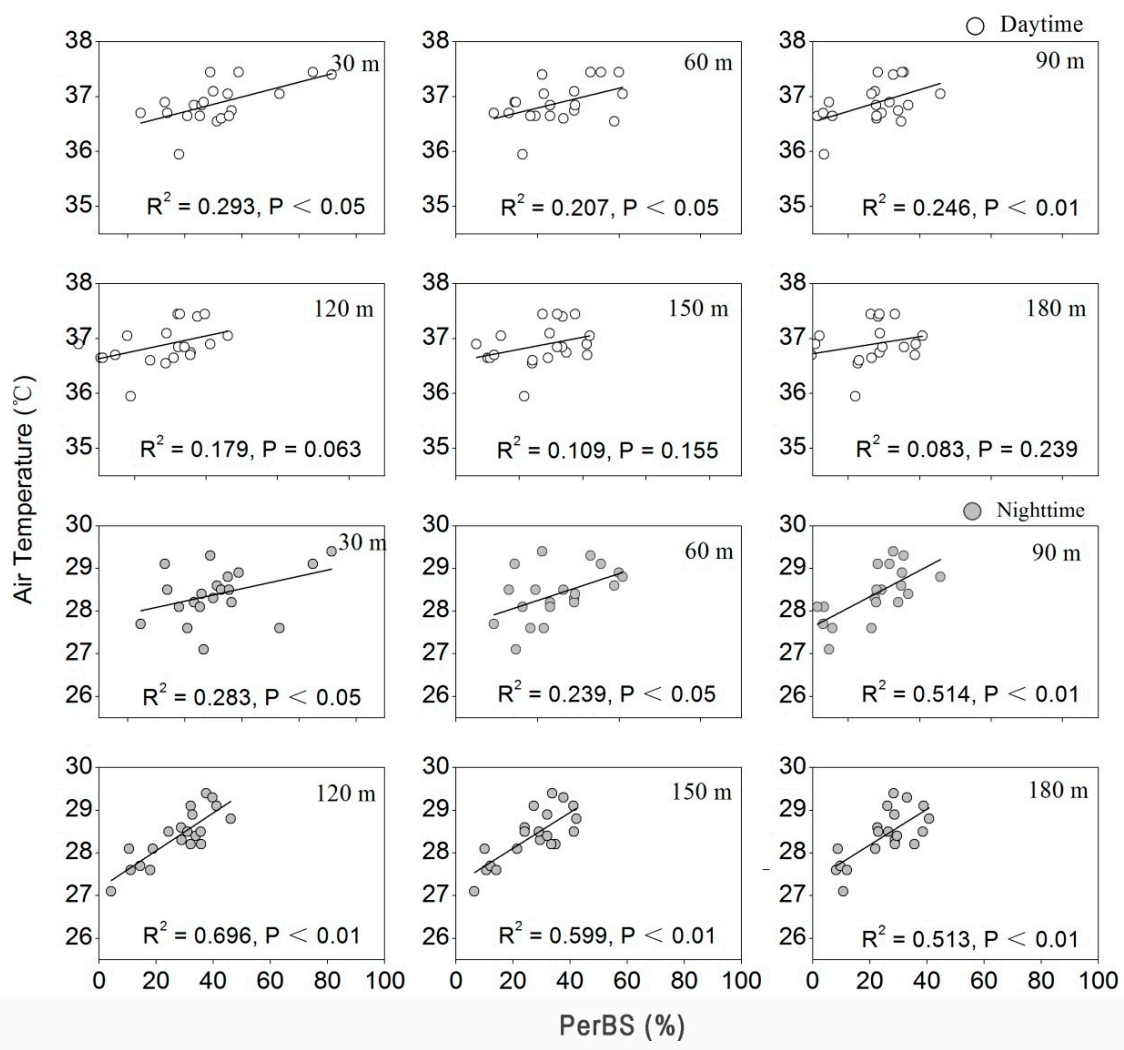

Figure 7. Relationships between air temperature and the percentage of building surface in different radii. 


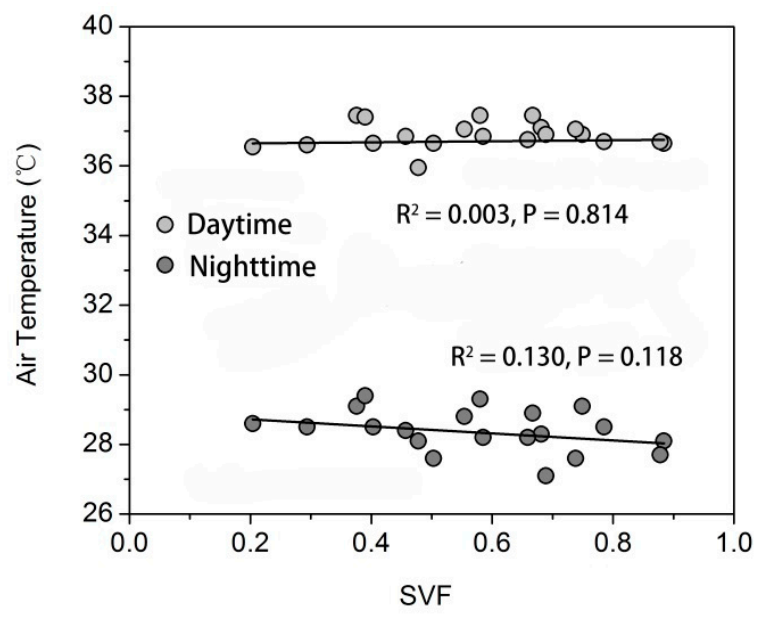

Figure 8. Relationships between the air temperature and sky view factor at different times.

\section{Discussion}

\subsection{Thermal Performance of Different LCZs}

It has been widely confirmed that spatial diversity could influence the outdoor thermal environment in many cities [43-46]. The results of our study indicated that all tested LCZ classes exhibited a temperature difference in summer [47]. The maximum air temperature contrast $\left(1.6^{\circ} \mathrm{C}\right)$ during the summer night was larger than during the day $\left(0.8^{\circ} \mathrm{C}\right)$. This was similar to the results of many previous UHI and LCZ studies conducted in different cities. The result that the spatial variability of AT within the respective LCZ was always lower than the differences between each LCZ confirms the application of the LCZ concept.

According to the LCZ theory, thermal contrasts are driven largely by building geometry and land cover under ideal conditions, which are calm and cloudless [26]. Contrasts between classes with significant differences in surface physical properties exceeded $5{ }^{\circ} \mathrm{C}$, whereas contrasts between classes with fewer physical differences were less than $2{ }^{\circ} \mathrm{C}$ in Uppsala, Nagano, and Vancouver [48]. In particular, our results indicated that during the hot summer night, the temperature contrast between LCZ 2 and LCZ 9 was as high as $1.6^{\circ} \mathrm{C}$. Th season might be the reason why the temperature contrast of our measurement was not close to $5^{\circ} \mathrm{C}$. Winter was hypothesized to be the season with the highest temperature contrasts in Beijing, China [42]. Gál et al. [49] found that the order of LCZ temperature varied with seasons, and the results of Thomas et al. [30] indicated that pre-dawn UHI intensity in winter was stronger than that in summer. Additionally, the temperature contrasts between LCZ 4 and LCZ 5, which had fewer physical differences than the other sites, did not exceed 1.1 and $0.7^{\circ} \mathrm{C}$, respectively, at the two different times of the day. Nevertheless, comparing LCZ temperature contrasts across all of the studies seemed to be difficult because of the various sample sizes. Ordering the LCZs by temperature was thought to be more valuable [33].

Generally, LCZ 1 or 2 had the highest nocturnal temperature [50]. However, LCZ 1 was not involved in the present study. AT of PSXC (LCZ 2) was the highest of all the LCZs in all mobile measurement campaigns, which was consistent with the studies of Lehnert et al. [33]. In agreement with the assumption of Stewart and Oke [26], the nocturnal temperatures of LSSJ, classified as LCZ 5, were, on average, lower than that of PSXC (LCZ 2). Similarly, LCZ 2 had higher nocturnal AT than LCZ 5 in Dublin and Nancy [28,34]. In addition, the ATs of site ZJHY (LCZ 4) were approximate to LCZ 5 because of the similar surface physical properties. The results of the present study showed that ZAFU (LCZ 9) was always the coolest built types of LCZs at night, which agrees with the findings in the reviewed papers $[33,51]$.

According to the LCZ classification, other factors influencing the temperature in urban areas (such as elevation, altitude, terrain morphology, general climatic conditions) are not included in the LCZ concept [26]. It is worth noting that some studies revealed that the AT 
measured within a certain LCZ may be influenced by its internal structure, position within (or beyond) the city, microclimatic effects, or pattern of circulation systems [29,34,46,52]. Besides, due to the existence of a buffer of mutually permeating types [33], the temperature might be influenced by the boundary between each LCZ, and its surroundings may be fuzzy.

\subsection{Effects of Land Cover Features on Outdoor Thermal Performance}

Temperature differences and distribution patterns in cities are mainly due to the thermal properties and energy balance of different underlying surfaces, which leads to the difference of AT near the ground [53]. Additionally, the influence of the underlying surface composition on the urban environmental temperature has been widely verified. In the present study, the observed AT significantly decreased when the PerPS increased during the summer nighttime, and the strongest effect radius was $120 \mathrm{~m}$. However, during the daytime, AT decreased with PerPS in a radius of 30 to $60 \mathrm{~m}$.

According to the theory put forward by Oke [54], the three main factors of urban heat energy balance are anthropogenic heat, latent heat, and sensible heat. Summer is the growing season of vegetation. During the daytime, vegetative cover mainly cools down the temperature in two ways [55-57]. First, the solar radiation absorbed by vegetation is partitioned into latent heat rather than sensible heat, reducing the solar radiation energy, which should be absorbed by the atmosphere. Second, the underlying surface receives less solar radiation because of the vegetation barrier. In this way, higher PerPS leads to lower AT. The shade provided by trees during the daytime produces an effect on a small scale. During the nighttime, the natural surface has a faster cooling rate than the artificial one, so site ZAFU (LCZ 9), which was covered by bush and trees, was the coldest spot with an AT lower than the average temperature.

However, an increase in PerIS would significantly increase AT. During the daytime, the solar radiation absorbed by the impervious surface is partitioned into sensible heat, resulting in a fast rise of AT. Lin et al. [58] showed that the surface temperature difference between pavements and vegetation at around midday could reach $10{ }^{\circ} \mathrm{C}$. At night, the higher heat capacity of the artificial impervious surface slowed cooling. Consistent with PerIS, the increase in PerBS would significantly increase AT. Besides, the increased building cover meant an increase of anthropogenic heat production, such as space heating, industrial operations, and automobile use. When it came to 14:00 in the afternoon, the temperature was the highest in one day. Additionally, the buildings became a big heat source, which released long-wave radiation. In the evening, the high building density and poor ventilation were not conducive to outward diffusion of heat. On a large scale in the study (in 60 to $180 \mathrm{~m}$ radius), AT increased with the increase of building coverage. In the evening, PSXC (LCZ 2), which was covered by the highest percentage of artificial surface, including PerIS and PerBS of all the LCZ types, always had ATs higher than the average temperature.

The increase of SVF made the increase of the radiation reception during the daytime and increased AT, while the increase of the out-going long-wave radiation during the nighttime decreased AT [59]. In our study, AT increased with the increase of SVF during the daytime, while a contrary tendency was observed during nighttime. We found no significant relationship between AT and SVF during both daytime and nighttime. One of the reasons that may explain the results was the position of visible sky [60]. Besides, we found that when testing the effects of SVF on air temperature, it is important to control for the potential effects from other landscape variables, particularly the land cover composition.

In conclusion, we found that AT was comprehensively influenced by the land coverage characteristics and urban structure. The sky view factor was affected by both surrounding buildings and trees. During the daytime, trees could decrease ATs by evaporation and the provision of shade. However, buildings blocked long-wave radiation from the ground, thus the remaining heat resulted in increased ATs [22]. 


\section{Conclusions}

With the LCZ concept, the effects of land cover composition and structure on the urban thermal environment in the high population density city of Hangzhou in the summer were investigated. The results showed that the maximum mean nighttime air temperature difference was $1.6{ }^{\circ} \mathrm{C}$. Furthermore, among the different LCZs, LCZs ordered by temperature that showed significance were LCZ $2>5>9>4$ during the daytime, and LCZ $2>4>5>9$ during the nighttime. The land cover features differentially contributed to the air temperature variability. On the one hand, the land cover composition could change the urban environmental temperature by influencing the factors of urban heat energy balance. Additionally, the most important landscape characteristic in explaining AT in different situations was PerPS. During the summer daytime and nighttime, increasing PerPS and decreasing PerIS and PerBS ameliorated the local thermal environment, with the strongest influence radius ranging from 120 to $150 \mathrm{~m}$. On the other hand, the land cover structure feature was important in the absorption and loss of radiation. It was observed that AT increased with SVF increasing in the day and the opposite was shown during the night.

These results confirm that the LCZ concept can be applied to urban temperature research. This kind of application will be beneficial to systematical and quantitative exploration of AT in different kinds of LCZs, and to further predict the urban climate. We suppose that a landscape design balancing the controllable land cover composition, such as adequate pervious surface, reasonable impervious surface, and building surface fraction in a certain range, should be taken into consideration to improve the urban thermal environment.

Author Contributions: Conceptualization, H.Y., S.Y., X.G., F.W., R.W., F.S. and Z.B.; methodology, H.Y., S.Y. and R.W.; investigation, S.Y., X.G. and R.W.; software, S.Y. and F.S.; resources, X.G., F.W. and F.S.; writing - original draft preparation, H.Y. and S.Y.; writing-review and editing, H.Y., S.Y. and Z.B. visualization, S.Y., X.G. and F.S. All authors have read and agreed to the published version of the manuscript.

Funding: This research was funded by Zhejiang Provincial Natural Science Foundation of China under Grant No. LGF21E080001 and National Natural Science Foundation of China under Grant No. 51508515.

Institutional Review Board Statement: Not applicable.

Informed Consent Statement: Not applicable.

Data Availability Statement: Not applicable.

Conflicts of Interest: The authors declare no conflict of interest.

\section{References}

1. Voogt, J.A.; Oke, T.R. Thermal remote sensing of urban climates. Remote Sens. Environ. 2003, 86, 370-384. [CrossRef]

2. Peng, S.; Piao, S.; Ciais, P.; Friedlingstein, P.; Ottle, C.; Bréon, F.-M.; Nan, H.; Zhou, L.; Myneni, R.B. Surface urban heat island across 419 global big cities. Environ. Sci. Technol. 2011, 46, 696-703. [CrossRef]

3. Levermore, G.; Parkinson, J.; Lee, K.; Laycock, P.; Lindley, S. The increasing trend of the urban heat island intensity. Urban Clim. 2018, 24, 360-368. [CrossRef]

4. Yadav, N.; Sharma, C. Spatial variations of intra-city urban heat island in megacity Delhi. Sustain. Cities Soc. 2018, 37, 298-306. [CrossRef]

5. Tan, J.; Zheng, Y.; Tang, X.; Guo, C.; Li, L.; Song, G.; Zhen, X.; Yuan, D.; Kalkstein, A.J.; Li, F.; et al. The urban heat island and its impact on heat waves and human health in Shanghai. Int. J. Biometeorol. 2010, 54, 75-84. [CrossRef]

6. Chen, F.; Yang, X.; Zhu, W. WRF simulations of urban heat island under hot-weather synoptic conditions: The case study of Hangzhou City, China. Atmos. Res. 2014, 138, 364-377. [CrossRef]

7. Oleson, K.W.; Monaghan, A.; Wilhelmi, O.; Barlage, M.; Brunsell, N.; Feddema, J.; Hu, L.; Steinhoff, D.F. Interactions between urbanization, heat stress, and climate change. Clim. Chang. 2015, 129, 525-541. [CrossRef]

8. Santamouris, M.; Cartalis, C.; Synnefa, A.; Kolokotsa, D. On the impact of urban heat island and global warming on the power demand and electricity consumption of buildings-A review. Energy Build. 2015, 98, 119-124. [CrossRef] 
9. Yang, J.; Yin, P.; Sun, J.; Wang, B.; Zhou, M.; Li, M.; Tong, S.; Meng, B.; Guo, Y.; Liu, Q. Heatwave and mortality in 31 major Chinese cities: Definition, vulnerability and implications. Sci. Total Environ. 2019, 649, 695-702. [CrossRef]

10. Cao, Q.; Yu, D.; Georgescu, M.; Wu, J.; Wang, W. Impacts of future urban expansion on summer climate and heat-related human health in eastern China. Environ. Int. 2018, 112, 134-146. [CrossRef]

11. Coseo, P.; Larsen, L. How factors of land use/land cover, building configuration, and adjacent heat sources and sinks explain Urban Heat Islands in Chicago. Landsc. Urban Plan. 2014, 125, 117-129. [CrossRef]

12. Doick, K.J.; Peace, A.; Hutchings, T.R. The role of one large greenspace in mitigating London's nocturnal urban heat island. Sci. Total Environ. 2014, 493, 662-671. [CrossRef] [PubMed]

13. Coccolo, S.; Kämpf, J.; Mauree, D.; Scartezzini, J.-L. Cooling potential of greening in the urban environment, a step further towards practice. Sustain. Cities Soc. 2018, 38, 543-559. [CrossRef]

14. Farhadi, H.; Faizi, M.; Sanaieian, H. Mitigating the urban heat island in a residential area in Tehran: Investigating the role of vegetation, materials, and orientation of buildings. Sustain. Cities Soc. 2019, 46. [CrossRef]

15. Sun, S.; Xu, X.; Lao, Z.; Liu, W.; Li, Z.; Garcia, E.H.; He, L.; Zhu, J. Evaluating the impact of urban green space and landscape design parameters on thermal comfort in hot summer by numerical simulation. Build. Environ. 2017, 123, 277-288. [CrossRef]

16. Quanz, J.; Ulrich, S.; Fenner, D.; Holtmann, A.; Eimermacher, J. Micro-scale variability of air temperature within a local climate zone in Berlin, Germany, during summer. Climate 2018, 6, 5. [CrossRef]

17. Yan, H.; Fan, S.; Guo, C.; Hu, J.; Dong, L. Quantifying the impact of land cover composition on intra-urban air temperature variations at a mid-latitude city. PLoS ONE 2014, 9, e102124. [CrossRef]

18. Xu, D.; Zhou, D.; Wang, Y.; Xu, W.; Yang, Y. Field measurement study on the impacts of urban spatial indicators on urban climate in a Chinese basin and static-wind city. Build. Environ. 2019, 147, 482-494. [CrossRef]

19. Eliasson, I. Urban nocturnal temperatures, street geometry and land use. Atmos. Environ. 1996, 30, 379-392. [CrossRef]

20. Vieira, H.; Vasconcelos, J. Urban morphology characterisation to include in a GIS for climatic purposes in Lisbon. Discussion of two different methods. In Proceedings of the 5th International Conference on Urban Climate, Łódź, Poland, 1-5 September 2003; Volume 2, pp. 417-420.

21. $\mathrm{Wu}, \mathrm{Z}$; Dou, P.; Chen, L. Comparative and combinative cooling effects of different spatial arrangements of buildings and trees on microclimate. Sustain. Cities Soc. 2019, 51. [CrossRef]

22. Oke, T.R. Canyon geometry and the nocturnal urban heat island: Comparison of scale model and field observations. J. Clim. 1981, 1, 237-254. [CrossRef]

23. Svensson, M.K. Sky view factor analysis-Implications for urban air temperature differences. Meteorol. Appl. 2004, 11, $201-211$. [CrossRef]

24. Unger, J. Intra-urban relationship between surface geometry and urban heat island: Review and new approach. Clim. Res. 2004, 27, 253-264. [CrossRef]

25. Hart, M.A.; Sailor, D.J. Quantifying the influence of land-use and surface characteristics on spatial variability in the urban heat island. Theor. Appl. Climatol. 2009, 95, 397-406. [CrossRef]

26. Stewart, I.D.; Oke, T.R. Local climate zones for urban temperature studies. Bull. Am. Meteorol. Soc. 2012, 93, 1879-1900. [CrossRef]

27. Emmanuel, R.; Krüger, E. Urban heat island and its impact on climate change resilience in a shrinking city: The case of Glasgow, UK. Build. Environ. 2012, 53, 137-149. [CrossRef]

28. Alexander, P.J.; Mills, G. Local climate classification and Dublin's urban heat island. Atmosphere 2014, 5, 755-774. [CrossRef]

29. Fenner, D.; Meier, F.; Scherer, D.; Polze, A. Spatial and temporal air temperature variability in Berlin, Germany, during the years 2001-2010. Urban Clim. 2014, 10, 308-331. [CrossRef]

30. Thomas, G.; Sherin, A.P.; Ansar, S.; Zachariah, E.J. Analysis of urban heat island in Kochi, India, using a modified local climate zone classification. Procedia Environ. Sci. 2014, 21, 3-13. [CrossRef]

31. Středová, H.; Středa, T.; Litschmann, T. Smart tools of urban climate evaluation for smart spatial planning. Morav. Geogr. Rep. 2015, 23, 47-57. [CrossRef]

32. Geletič, J.; Lehnert, M.; Dobrovolný, P. Land surface temperature differences within local climate zones, based on two central European cities. Remote Sens. 2016, 8, 788. [CrossRef]

33. Lehnert, M.; Geletič, J.; Dobrovolný, P.; Jurek, M. Temperature differences among local climate zones established by mobile measurements in two central European cities. Clim. Res. 2018, 75, 53-64. [CrossRef]

34. Leconte, F.; Bouyer, J.; Claverie, R.; Pétrissans, M. Using Local Climate Zone scheme for UHI assessment: Evaluation of the method using mobile measurements. Build. Environ. 2015, 83, 39-49. [CrossRef]

35. Geletič, J.; Lehnert, M.; Savić, S.; Milošević, D. Modelled spatiotemporal variability of outdoor thermal comfort in local climate zones of the city of Brno, Czech Republic. Sci. Total Environ. 2018, 624, 385-395. [CrossRef] [PubMed]

36. Krüger, E.; Rossi, F.A. Effect of personal and microclimatic variables on observed thermal sensation from a field study in southern Brazil. Build. Environ. 2011, 46, 690-697. [CrossRef]

37. Skarbit, N.; Gál, T.; Unger, J. Airborne surface temperature differences of the different Local Climate Zones in the urban area of a medium sized city. In Proceedings of the 2015 Joint Urban Remote Sensing Event (JURSE), Lausanne, Switzerland, 30 March-1 April 2015; pp. 1-4. 
38. Nassar, A.K.; Blackburn, G.A.; Whyatt, J.D. Dynamics and controls of urban heat sink and island phenomena in a desert city: Development of a local climate zone scheme using remotely-sensed inputs. Int. J. Appl. Earth Obs. Geoinf. 2016, 51, 76-90. [CrossRef]

39. Kottek, M.; Grieser, J.; Beck, C.; Rudolf, B.; Rubel, F. World map of the Köppen-Geiger climate classification updated. Meteorol. Z. 2006, 15, 259-263. [CrossRef]

40. Peel, M.C.; Finlayson, B.L.; McMahon, T.A. Updated world map of the Köppen-Geiger climate classification. Hydrol. Earth Sys. Sci. 2007, 4, 439-473.

41. Kong, F.; Yin, H.; James, P.; Hutyra, L.R.; He, H.S. Effects of spatial pattern of greenspace on urban cooling in a large metropolitan area of eastern China. Landsc. Urban Plan. 2014, 128, 35-47. [CrossRef]

42. Yan, H.; Fan, S.; Guo, C.; Wu, F.; Zhang, N.; Dong, L. Assessing the effects of landscape design parameters on intra-urban air temperature variability: The case of Beijing, China. Build. Environ. 2014, 76, 44-53. [CrossRef]

43. Atkinson, B.W. Numerical modelling of urban heat-island intensity. Bound. Layer Meteorol. 2003, 109, 285-310. [CrossRef]

44. Giridharan, R.; Lau, S.S.Y.; Ganesan, S.; Givoni, B. Urban design factors influencing heat island intensity in high-rise high-density environments of Hong Kong. Build. Environ. 2007, 42, 3669-3684. [CrossRef]

45. Gulyás, Á.; Unger, J.; Matzarakis, A. Assessment of the microclimatic and human comfort conditions in a complex urban environment: Modelling and measurements. Build. Environ. 2006, 41, 1713-1722. [CrossRef]

46. Yang, X.; Yao, L.; Jin, T.; Peng, L.L.; Jiang, Z.; Hu, Z.; Ye, Y. Assessing the thermal behavior of different local climate zones in the Nanjing metropolis, China. Build. Environ. 2018, 137, 171-184. [CrossRef]

47. Fan, S.; Li, X.; Han, J.; Hao, P.; Dong, L. Assessing the effects of landscape characteristics on the thermal environment of open spaces in residential areas of Beijing, China. Landsc. Ecol. Eng. 2018, 14, 79-90. [CrossRef]

48. Stewart, I.D.; Oke, T.R.; Krayenhoff, E.S. Evaluation of the 'local climate zone' scheme using temperature observations and model simulations. Int. J. Clim. 2014, 34, 1062-1080. [CrossRef]

49. Gál, T.; Skarbit, N.; Unger, J. Urban heat island patterns and their dynamics based on an urban climate measurement network. Hung. Geogr. Bull. 2016, 65, 105-116. [CrossRef]

50. Oke, T.R. The energetic basis of the urban heat island. Q. J. R. Meteorol. Soc. 1982, 108. [CrossRef]

51. Herbel, I.; Croitoru, A.-E.; Rus, I.; Harpa, G.V.; Ciupertea, A.-F. Detection of atmospheric urban heat island through direct measurements in Cluj-Napoca city, Romania. Hung. Geogr. Bull. 2016, 65, 117-128. [CrossRef]

52. Skarbit, N.; Stewart, I.D.; Unger, J.; Gál, T. Employing an urban meteorological network to monitor air temperature conditions in the 'local climate zones' of Szeged, Hungary. Int. J. Clim. 2017, 37, 582-596. [CrossRef]

53. Lin, P.; Gou, Z.; Lau, S.; Qin, H. The impact of urban design descriptors on outdoor thermal environment: A literature review. Energies 2017, 10, 2151. [CrossRef]

54. Oke, T.R. The urban energy balance. Prog. Phys. Geogr. Earth Environ. 1988, 12, 471-508. [CrossRef]

55. Yokobori, T.; Ohta, S. Effect of land cover on air temperatures involved in the development of an intra-urban heat island. Clim. Res. 2009, 39, 61-73. [CrossRef]

56. Gago, E.J.; Roldan, J.; Pacheco-Torres, R.; Ordonez, J. The city and urban heat islands: A review of strategies to mitigate adverse effects. Renew. Sustain. Energy Rev. 2013, 25, 749-758. [CrossRef]

57. Srivanit, M.; Hokao, K. Evaluating the cooling effects of greening for improving the outdoor thermal environment at an institutional campus in the summer. Build. Environ. 2013, 66, 158-172. [CrossRef]

58. Lin, T.-P.; Ho, Y.-F.; Huang, Y.-S. Seasonal effect of pavement on outdoor thermal environments in subtropical Taiwan. Build. Environ. 2007, 42, 4124-4131. [CrossRef]

59. Oliveira, S.; Andrade, H.; Vaz, T. The cooling effect of green spaces as a contribution to the mitigation of urban heat: A case study in Lisbon. Build. Environ. 2011, 46, 2186-2194. [CrossRef]

60. Qaid, A.; Bin Lamit, H.; Ossen, D.R.; Rasidi, M.H. Effect of the position of the visible sky in determining the sky view factor on micrometeorological and human thermal comfort conditions in urban street canyons. Theor. Appl. Clim. 2018, 131, 1083-1100. [CrossRef] 